\title{
Antimicrobial, Antipyretic, and Anti-Inflammatory Activities of Selected Philippine Medicinal Pteridophytes
}

\author{
VICTOR B. AMOROSO \\ ORCID No. 0000-0001-8865-5551 \\ victoramoroso@gmail.com \\ Central Mindanao University \\ DOROTHY A. ANTESA \\ ORCID No. 0000-0003-1961-1867 \\ daantesa.orcid@gmail.com \\ Notre Dame of Marbel University \\ DAVE P. BUENAVISTA \\ ORCID No. 0000-0002-1636-0399 \\ dpbuenavista.orcid@gmail.com \\ FULGENT P. CORITICO \\ ORCID No. 0000-0003-3876-6610 \\ fcoritico.orcid@gmail.com \\ Central Mindanao University
}

\begin{abstract}
Pteridophytes are some of the herbal plants used to cure ailments. The present study scientifically finds out the folkloric therapeutic claims of 15 species of Philippine medicinal pteridophytes. Phytochemical components namely alkaloids, flavonoids, saponins, tannins, and anthraquinones of each plant samples were qualitatively determined. Antimicrobial activity of ethanolic extract
\end{abstract}


was tested on Staphylococcus aureus, Bacillus subtilis, Escherichia coli, Pseudomonas aeruginosa, and Candida albicans. The antipyretic activity using yeast-induced pyrexia and the anti-inflammatory activity using egg-albumin-induced paw edema were done on white rats. The results revealed the presence of alkaloids, saponins, flavonoids, and tannins in most of the extracts. Anthraquinones were absent. Extract form three species of pteridophytes namely: Equisetum ramosissimum, Pyrrosia piloselloides, and Selaginella usterii did not manifest any antibacterial activity. Blechnum orientale has no antifungal activity. All extracts showed significant effect in reducing yeast-induced pyrexia when compared with the negative control (NSS). Fourteen (14) out of the fifteen (15) plant extracts in $400 \mathrm{mg} / \mathrm{kg}$ Body Weight dosage inhibited anti-inflammatory activities in eggalbumin induced rat paw edema except for Pyrossia piloselloides. However, all plant extracts in $800 \mathrm{mg} / \mathrm{kg}$ Body Weight dosage showed significant rat paw reduction. A dose-dependent anti-inflammatory effect was observed within 6 hours of paw thickness observation.

Keywords - Phytochemicals, Ferns, Bioassay, Philippines

\section{INTRODUCTION}

Natural products, such as plant extract, either as pure compounds or as standardized extracts, provide unlimited opportunities for new drug discoveries because of the unmatched chemical diversity they can provide (Cos et al. 2006). These compounds are significant in therapeutic application against pathogens, including bacteria, fungi and viruses (Khan et al. 2003). Some of these medicinal plants with reported medicinal value belong to the family of pteridophytes or ferns and their allies.

Pteridophytes are a group of plants commonly used as a source of medicine, food, ornamentals, as sources of fiber, bioremediation, and as organic fertilizer. Studies on the medicinal potentials of these plants have been very few as reflected from scarce literature. Indeed, out of 1,100 species only more than 50 species of these plants were reported to have medicinal values throughout the Philippines and 41 species of which can be found in Mindanao (Amoroso 2013).

In this study, selected pteridophytes with medicinal value were gathered, identified, screened for their phytochemical components and were evaluated for their antimicrobial, antipyretic, and anti-Inflammatory activities. 


\section{OBJECTIVES OF THE STUDY}

This study was conducted to evaluate the folkloric therapeutic claims of some Philippine medicinal pteridophytes by determining their phytochemical and pharmacologic properties.

Specifically, it aimed to (1). find out qualitatively the presence of the phytochemicals on the ethanolic plant extracts; (2). determine if the ethanolic plant extracts have antifungal activity on Candida albicans; (3). determine if the ethanolic plant extracts have antibacterial activity on the Gram positive Staphylococcus aureus and Bacillus subtilis and on Gram negative Escherichia coli and Pseudomonas aeruginosa; and, (4) assess whether the ethanolic plant extracts of the pteridophytes have antipyretic and anti-inflammatory activities.

\section{MATERIALS AND METHODS}

\section{A. Collection and Processing of Specimens}

Fifteen (15) species of pteridophytes were collected in the campus of Notre Dame of Marbel University (NDMU), City of Koronadal, Mt. Salumay, Marilog District, Davao City and Mt. Kiamo in Malaybalay, Bukidnon (Plate I). These were wrapped individually in clean plastic bags and were brought to Central Mindanao University, Musuan, Bukidnon for identification, confirmation, and preparation of herbarium specimens. Fresh, free from insect bites, and intact pteridophyte fronds were collected and brought to NDMU for the biological assay.

Ethanol Extraction:

Fronds of the plants were cleaned and two hundred grams $200 \mathrm{~g}$ fresh weights of each plant were weighed separately. These were then separately chopped into small pieces and were placed in conical flasks. Ninety-five percent ethanol was added to each flask until the plant parts were completely submerged. The plant materials were soaked in ethanol for 24 hours. Filtration was done on each sample and the filtrates were concentrated in a rotary evaporator at a temperature of $45^{\circ} \mathrm{C}$. The concentrates of each fern fronds were measured and stored in properly labeled vials. The concentration of the extract was computed and expressed as 
grams fern frond per $\mathrm{mL}$ of extract. The concentrated ethanolic crude extracts were then stored in the refrigerator to prevent the growth of microorganisms.

B. Phytochemical Analysis

Phytochemical screening of the plant extracts was carried out as per the methods described by Guevarra (2005).

Test for Alkaloids

An equivalent of $20 \mathrm{~g}$ plant material from the stock plant extract was placed in an evaporating dish. This was evaporated to a syrupy consistency over a steam bath. Five (5) $\mathrm{mL}$ of $2 \mathrm{M}$ hydrochloric acid $(\mathrm{HCl})$ was added and was stirred for about 5 minutes and was allowed to cool. One $\mathrm{mL}$ of the filtrate was tested with 2 to 3 drops of Dragendorff's reagent. Another $1 \mathrm{~mL}$ of the filtrate was tested with 2 to 3 drops of Meyer's Reagent. The relative amount of precipitation was observed as follows: $(+)$ slight turbidity; $(++)$ definite turbidity; and (+++) heavy precipitation. Aside from the above test, the following were conducted:
a. Test for quarternary bases and/or amine oxide
b. Test for Saponins (Froth Test)
c. Test for Flavonoids
d. Test for leucoanthocyanins by Bate-Smith and Metcalf method
e. Test for $\gamma$-benzopyrone nucleus: Wilstatter "cyanidin" test
f. Test for Tannins
g. Gelatin Test
h. Ferric Chloride Test
i. $\quad$ Test for Anthraquinones (Borntrager's Test)

C. Antimicrobial Assay by Agar Well Diffusion Method

The antimicrobial testing was carried out using the methods described by Guevarra (2005).

a. Preparation of Liquid Media for the Inoculum

b. Sterilization Techniques

c. Inoculation of Test organisms 
d. Preparation of Base Plate and Top Agar

e. Preparation of Treatments

f. Delivery of the extract into the Agar wells and determination of equivalent antibiotic concentration

D. In-vivo Antipyretic and Anti-inflammatory Screening

\section{D1. Preparation of Test Animals}

Mature male albino rats weighing $80-115 \mathrm{~g}$ body weight (BW) were used. The animals were housed in steel cages with wooden frames under standard and hygienic conditions as they were acclimatized to laboratory conditions 7 weeks prior to experimentation. Prior to treatment administration, they were made to fast for 16 hours with water ad libitum. Rats were weighed using a digital balance and were numbered in comparable groups according to the treatment they were subjected to. The animal assays were carried out following the principles of good laboratory practice and animal handling (National Institutes of Health Guide for the Care and use for Laboratory animals; Publication No. 85-23, revised 1985).

\section{D2. Test for Anti-pyretic Activity}

The anti-pyretic activity of the ethanolic frond extract of the selected pteridophytes was carried out using the methods modified from Al-Ghamdi (2001).

One hundred fifty male albino rats were individually weighed and the baseline body temperature of each rat was taken by inserting a flexible digital thermometer into the rectum for about 2 minutes. The steady temperature readings obtained were recorded as the pre-treatment or baseline body temperatures. Pyrexia was induced in rats by the administration of $1 \mathrm{~mL} / \mathrm{kg}$ BW of $15 \%$ baker's yeast suspension intraperitoneally (i.p.). Nineteen hrs after yeast administration, the rectal temperatures were remeasured. Rats that did not show a minimum increase of $0.5^{\circ} \mathrm{C}$ were eliminated from the study. Eighty-five rats with fever were divided into 17 groups of 5 rats each. Each of the 15 groups received immediately 800 $\mathrm{mg} / \mathrm{kg}$ of the ethanolic frond extract dissolved in Normal Saline Solution (NSS). One group received NSS and the last group received $150 \mathrm{mg} / \mathrm{kg}$ paracetamol. All treatments were administered intraperitoneally. 


\begin{abstract}
D3. Test for Anti-inflammatory Activity (Egg albumin-induced rat paw edema)
\end{abstract}

The method used in screening for the anti-inflammatory potential of the extracts is a modification of the protocol employed by Winter et al. (1962).

One hundred seventy male albino rats (80-110 grams) were divided into groups of 10 rats. Four hundred $\mathrm{mg} / \mathrm{kg} \mathrm{BW}$ and $800 \mathrm{mg} / \mathrm{kg}$ BW of each ethanolic frond extract were injected intraperitoneally to rats. Diclofenac sodium $50 \mathrm{mg} / \mathrm{kg}$ BW was used as standard anti-inflammatory drug for extract comparison. NSS served as the negative control. Ethanolic frond extracts were injected one hour prior to egg-albumin injection.

Egg-albumin edema was induced by injecting subcutaneously (s.c.) $0.1 \mathrm{~mL}$ of egg albumin (Salawu et al. 2008) into the plantar region of the right hind paws of the rats. Two hours after albumin administration, the thickness of the right paw was measured with a Vernier caliper. This was repeated after 4 hours and 6 hours.

The percentage increase in paw thickness every 2 hours was also calculated. The percentage inhibition of edema was calculated for each extract using the formula by Perez (1986).

$$
\begin{aligned}
& \text { \% Inhibition }=100(1-(\mathrm{a}-\mathrm{x} / \mathrm{b}-\mathrm{y})) \\
& \begin{aligned}
\text { Where: } \mathrm{a} & =\text { mean paw volume of treated animals after egg albumin injection } \\
\mathrm{x} & =\text { mean paw volume of treated animals before egg albumin injection } \\
\mathrm{b} & =\text { mean paw volume of control animals after egg albumin injection } \\
\mathrm{y} & =\text { mean paw volume of control animals before egg albumin injection }
\end{aligned}
\end{aligned}
$$

\title{
RESULTS AND DISCUSSION
}

Phytochemical Screening

Phytochemicals are non-nutritive plant chemicals that have protective or disease preventing properties for the plant. Fifteen (15) Philippine medicinal pteridophytes viz., Adiantum philippense Linn., Asplenium nidus Linn., Blechnum orientale Linn., Cyathea contaminans (Hook.) Copel., Dicranopteris linearis (Burm.) Underw., Diplazium esculentum (Retz) Sw., Drynaria quercifolia (Linn.) J. Sm., Equisetum ramosissimum (Roxb.) Hauke, Lygodium microphyllum (Cav.) R. Br., Microsorum punctatum (Linn.) Copel., Nephrolepis cordifolia (Linn.) Presl., Oleandra pistillaris (Sw.) C. Chr., Pteridium aquilinum (Linn.) Kuhn, 
Pyrrosia piloselloides (Linn.) Price, and Selaginella usterii Linn. were subjected to phytochemical screening following the procedure of Guevarra (2005). Five phytochemicals were qualitatively evaluated namely: alkaloids, saponins, flavonoids, tannins, and anthraquinones (Appendix 1).

\section{Alkaloids}

The results (Table 1) showed that except for Selaginella usterii, fourteen (14) pteridophyte ethanolic extracts have detectable alkaloids of either primary, secondary, and/or quarternary and/or amine oxides when tested with Meyer's and Dragendorff's reagent and only Selaginella usterii does not have detectable alkaloids by the method. Alkaloids generally have been noted for their antimalarial and antibacterial activities although it seems their mechanism of action on microbes remains unclear (Raghavendra et al. 2008).

\section{Saponins}

Saponins are present in the ehtanolic extracts of Blechnum orientale, Cyathea contaminans, Dicranopteris linearis, Diplazium esculentum, Drynaria quercifolia, Equisetum ramosissimum, Nephrolepis cordifolia, Oleandra pistillaris and Pyrrosia piloselloides. The relevant properties include membranolytic effects, toxic and fungitoxic effects, adverse effects on animal growth and performance, and the important hypocholesterolemic effect (Price et al. 1997). Saponins are also claimed to possess immunostimulatory and anticarcinogenic properties (Rao and Koratkar 1997).

\section{Flavonoids}

Flavonoids are present in all the extracts both in the form of leucoanthocyanins and/or y-benzopyrone. They possess important pharmacological properties (Porter 1989) and been recognized to have anti-inflammatory, anti-coagulant and aphrodisiac properties (Zabri et al. 2008). In the study of Mutalik et al. (2003), the dry residue of fresh juice of Solanum melongena produced significant antipyretic effect in a dose dependent manner. The antipyretic activity they observed was attributed to the presence of flavonoids. In many studies, flavonoids have been reported to exhibit antipyretic claims by traditional medicine practitioners (Vimala et al. 1997). 


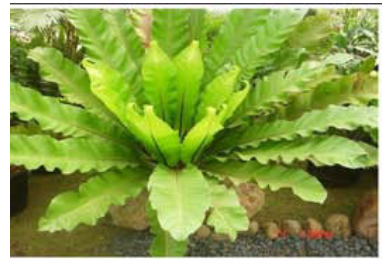
Asplenium nidus Linn

Pakpak Lauin; Pasdak; Pugad Lauin:

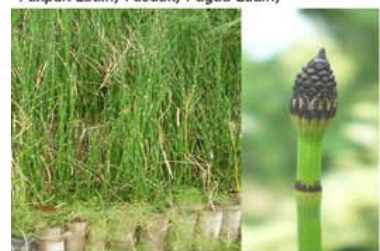

Equisetum ramosissimum (Roxb.) Hauke EQUISETACEAE

Horsetail

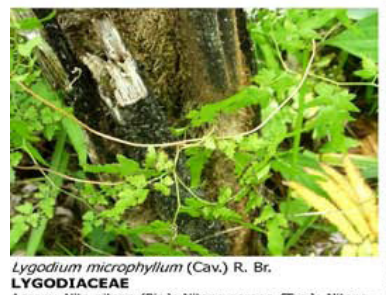

LYGODIACEAE

Agsam; Nito-nitoan (Bis.); Nitong-parang (Tag.); Nitong-

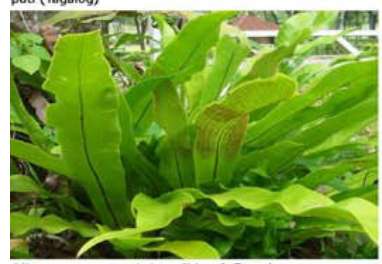

Microsorum punctatum (Linn.) Copel.

POLYPODIACEAE

(Igorot, Luzon)

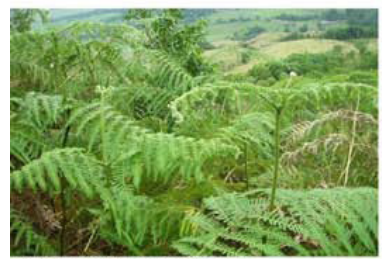

Pteridim aquilinum (Linn.) Kuhn

PTERIDACEAE

Bracken fern; Brake; Pasture Brake; Eagle Fern;

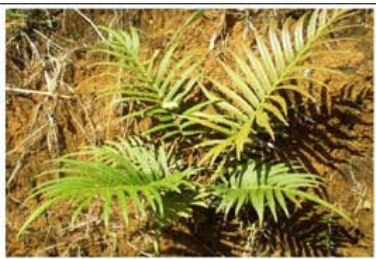
Blechnum orientale Linn BLECHNACEAE

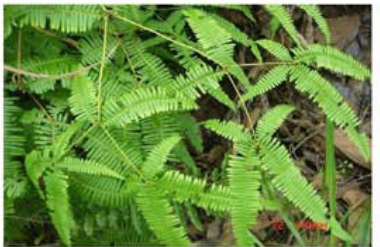
Dicranopteris linearis (Burm.) Underw. Scrambling fern; Gapingoí; Kilob; Tilub

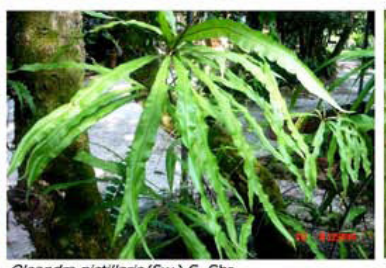

Oleandra pistillaris (Sw.) C. Chr.

OLEANDRACEAE

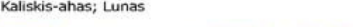

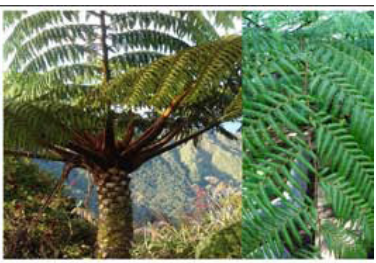

Cyathea contaminans (Hook.) Copel. CYATHEACEAE

Tree fern; Anonotong; Gantaw; Pakong buaya

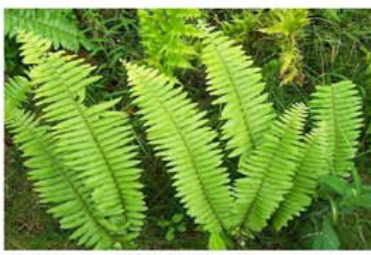

Nephrolepis cordifolia (Linn.) Pres!

\section{SIDACEAE}

Sword Fern; Erect Sword Fern; Fishbone Fern;

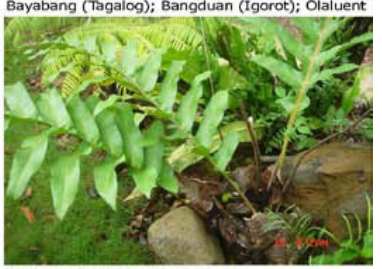

Drynaria quercifolia (Linn.) J. Sm.

POLYPODIACEAE

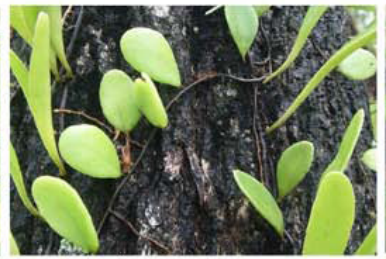

Pyrrosia pilloselloides (Linn.) Price

POLYPODIACEAE

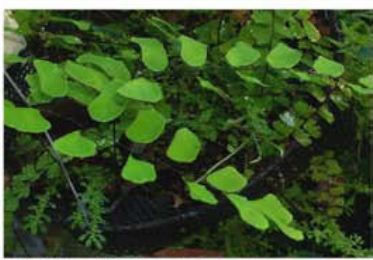

Adiantum phillippense Linn.

PTERIDACEAE Maidentillo, Palsik:

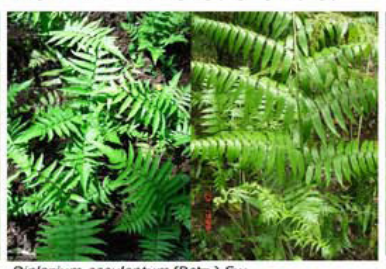

Diplazium esculentum (Retz.) Sw.

WOODSIACEAE
Edible fern; Pako; Tagabas.

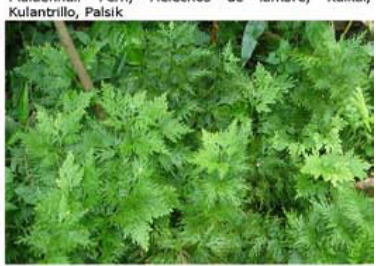

Selaginel/a usteri/ Linn.

SELAGINELLACEAE

Plate I. The 15 Species of Medicinal Pteridophytes used in the Study 


\section{Tannins}

Tannins in the form of hydrolysable and condensed tannins are present in most of the extracts except for Microsorum punctatum, Pyrrosia piloselloides, and Selaginella usterii. Hydrolyzable tannins have been shown to be effective antagonists against viruses, bacteria, (Funatogawa et al. 2004) and antiparasites (Kolodziej and Kiderlen 2005). In the past few years tannins have also been studied for their potential effects against cancer through different mechanisms

\section{Anthraquinones}

Anthraquinones were not detected in all fifteen (15) ethanolic extracts of pteridophyte fronds. Anthraquinones are the largest group of naturally occurring quinones. Both natural and synthetic anthraquinones have been widely used as colorants in food, drugs, cosmetics, hair dyes and textiles (Mori et al. 1990). Herbs containing anthraquinone derivatives are used as laxatives (Sonnenberg and Muller 1993). Based on this information, the absence of anthraquinones in the pteridophyte extract in this study may prevent the occurrence of diarrhea when the plant extracts are administered orally as herbal remedy.

Knowledge of the chemical constituents of plants is desirable, not only for the discovery of therapeutic agents, but also because such information may be of value in disclosing new sources of such economic materials as tannins, oils, gums, and precursors for the synthesis of complex chemical substances. In addition, knowledge of the chemical constituents of plants would further be valuable in discovering the economic and health benefits of folkloric remedies (Mojab et al. 2003). 


\begin{tabular}{|c|c|c|c|c|c|c|c|c|c|c|c|c|}
\hline \multirow{15}{*}{$\frac{n}{7}$} & $\omega$ & ' & 1 & 1 & 1 & 1 & I & ' & + & I & I & ' \\
\hline & $\hat{\Xi}$ & + & + & + & + & + & + & ' & + & 1 & + & . \\
\hline & 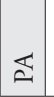 & $\stackrel{+}{+}$ & + & + & + & $\begin{array}{l}+ \\
+ \\
+\end{array}$ & 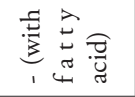 & + & + & + & + & ' \\
\hline & $\overline{0}$ & + & + & + & + & $\stackrel{+}{+}$ & + & + & + & + & + & 1 \\
\hline & Z & + & + & + & + & 1 & + & + & + & + & + & ' \\
\hline & $\stackrel{\xi}{\Sigma}$ & 1 & + & + & 1 & 1 & ' & ' & + & 1 & 1 & ' \\
\hline & $\sum_{1}$ & + & + & + & ' & $\stackrel{+}{+}$ & 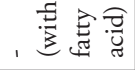 & + & + & + & + & ' \\
\hline & 寽 & 1 & \pm & + & + & 1 & + & ' & + & + & + & ' \\
\hline & $\begin{array}{l}\alpha \\
0\end{array}$ & \pm & $\begin{array}{l}+ \\
+ \\
+ \\
\end{array}$ & + & + & + & + & ' & + & + & + & . \\
\hline & 贸 & 1 & + & $\stackrel{+}{+}$ & . & $\stackrel{+}{+}$ & + & ' & + & + & + & 1 \\
\hline & $\overrightarrow{\vec{\theta}}$ & $\stackrel{+}{+}$ & + & + & + & + & + & + & + & + & + & , \\
\hline & $u$ & + & + & $\stackrel{+}{+}$ & . & $\stackrel{+}{+}$ & + & + & + & + & + & . \\
\hline & ○ & $\begin{array}{l}+ \\
+ \\
+\end{array}$ & $\begin{array}{l}+ \\
+ \\
+ \\
\end{array}$ & + & . & . & + & + & + & + & + & I \\
\hline & Z & + & + & $\stackrel{+}{+}$ & ' & + & ，趋氙兽 & ' & + & + & + & ' \\
\hline & \& & + & + & $\stackrel{+}{+}$ & ' & + & ' & 1 & + & + & + & 1 \\
\hline \multirow[t]{2}{*}{$\stackrel{\mathscr{y}}{\oplus}$} & & \multirow[b]{2}{*}{ 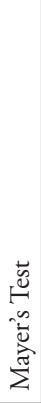 } & \multirow[b]{2}{*}{ 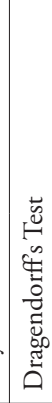 } & 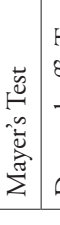 & 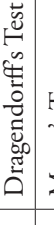 & 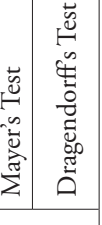 & & 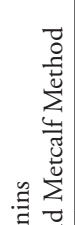 & 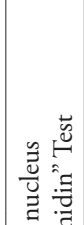 & & $\stackrel{\overrightarrow{⿱ 艹 ⿹ 勹 亾 丿}}{\oplus}$ & \\
\hline & & & & \multicolumn{2}{|c|}{ 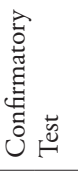 } & 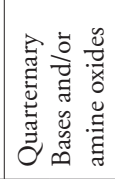 & 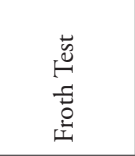 & 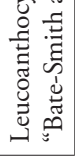 & 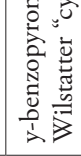 & 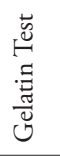 & 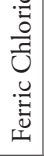 & 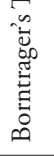 \\
\hline 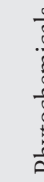 & 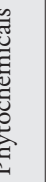 & \multicolumn{5}{|c|}{$\begin{array}{l}\frac{y}{0} \\
\frac{0}{0} \\
\frac{\vec{y}}{2}\end{array}$} & 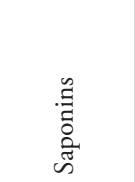 & \multicolumn{2}{|c|}{$\begin{array}{l}\frac{n}{0} \\
0 \\
0 \\
0 \\
\frac{\pi}{I}\end{array}$} & 节 & & 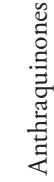 \\
\hline
\end{tabular}


Legend: AP (Adiantum philippense Linn.); AN (Asplenium nidus Linn.); BO (Blechnum orientale Linn.); CC (Cyathea contaminans (Hook.) Copel.); DL (Dicranopteris linearis (Burm.) Underw.); DE (Diplazium esculentum (Retz) Sw.); DQ (Drynaria quercifolia (Linn.) J. Sm.); ER (Equisitum ramosissimum (Roxb.) Hauke); LM (Lygodium microphyllum (Cav.) R. Br.); MP (Microsorum punctatum (Linn.) Copel.); NC (Nephrolepis cordifolia (Linn.) Presl.); OP (Oleandra pistillaris (Sw.) C. Chr.); PA (Pteridium aquilinum (Linn.) Kuhn); PP (Pyrrosia piloselloides (Linn.) Price); and SU (Selaginella usterii Linn.)

Alkaloid Mayer's and Dragendorff's Test: $(+)$ slight turbidity;

$(++)$ definite turbidity; $(+++)$ heavy precipitation

Confirmatory Test: $(+)$ primary alkaloid; $(++)$ secondary alkaloid;

$(+++)$ tertiary alkaloid

Test for quarternary bases and/or amine oxide: $(+)$ absent; $(++)$

or $(+++)$ present

Test for Saponins, Tannins, and Anthraquinones: (+) present; (-) absent

\section{Antimicrobial Assay}

The search for antimicrobial potential among medicinal pteridophytes was performed on the ethanolic extract of their fronds (Plate 2). Among the 15 pteridophytes evaluated, the following were attained: 1) Twelve (12) plant extracts inhibited the growth of Bacillus subtilis 2) Eight (8) inhibited the growth of Escherichia coli, 3) Eleven (11) plant extracts inhibited the growth of Pseudomonas aeruginosa, 4) Six (6) plant extracts inhibited the growth of Staphylococcus aureus, and 5) Fourteen (14) plant extracts inhibited the growth of Candida albicans. Among the fifteen pteridophytes plant extracts, Equisetum ramosissimum, Pyrrosia piloselloides, and Selaginella usterii extract did not show any antibacterial activity on all the four (4) bacterial isolates (Table 2).

The antibiotic equivalents were consistently and relatively high in Asplenium nidus, Blechnum orientale, Dicranopteris linearis, Oleandra pistillaris, and Pteridium aquilinum extracts when compared with the three antibiotics Amikacin, Ampicillin, and Streptomycin (Figures 1-3). 
Table 2. Zones of inhibition $(\mathrm{mm})$ of the ethanolic plant extract on the five (5) microbial isolates

\begin{tabular}{|l|l|l|l|l|l|}
\hline \multirow{2}{*}{ Plant Extract } & \multicolumn{5}{|c|}{ Mean Zones of Inhibition (mm) } \\
\cline { 2 - 6 } & B. subtilis & S. aureus & E.coli & P. aeruginosa & C. albicans \\
\hline Adiantum philippense & $10.33^{\mathrm{e}, \mathrm{f}}$ & $8.00^{\mathrm{e}}$ & $8.00^{\mathrm{e}}$ & $12.67^{\mathrm{e}}$ & $16.00^{\mathrm{d}}$ \\
\hline Asplenium nidus & $14.33^{\mathrm{c}}$ & $14.00^{\mathrm{c}}$ & $14.33^{\mathrm{d}}$ & $22.33^{\mathrm{a}}$ & $18.00^{\mathrm{c}}$ \\
\hline Blechnum orientale & $20.67^{\mathrm{b}}$ & $20.00^{\mathrm{a}}$ & $19.67^{\mathrm{b}}$ & $17.67^{\mathrm{b}}$ & $8.00^{\mathrm{g}}$ \\
\hline Cyathea contaminans & $12.67^{\mathrm{d}}$ & $11.33^{\mathrm{d}}$ & $12.67^{\mathrm{e}}$ & $13.67^{\mathrm{d}, \mathrm{e}}$ & $15.33^{\mathrm{d}, \mathrm{e}}$ \\
\hline Dicranopteris linearis & $21.67^{\mathrm{a}}$ & $16.67^{\mathrm{b}}$ & $17.33^{\mathrm{c}}$ & $15.33^{\mathrm{c}}$ & $14.00^{\mathrm{e}}$ \\
\hline Diplazium esculentum & $13.00^{\mathrm{d}}$ & $8.00^{\mathrm{e}}$ & $17.67^{\mathrm{c}}$ & $14.33^{\mathrm{c}, \mathrm{d}}$ & $19.67^{\mathrm{a}, \mathrm{b}}$ \\
\hline Drynaria quercifolia & $11.00^{\mathrm{e}}$ & $8.00^{\mathrm{e}}$ & $8.00^{\mathrm{e}}$ & $9.33^{\mathrm{f}}$ & $18.00^{\mathrm{c}}$ \\
\hline Equisetum ramosissimum & $8.00^{\mathrm{g}}$ & $8.00^{\mathrm{e}}$ & $8.00^{\mathrm{e}}$ & $8.00^{\mathrm{g}}$ & $16.33^{\mathrm{d}}$ \\
\hline Lygodium microphyllum & $10.00^{\mathrm{f}}$ & $8.00^{\mathrm{e}}$ & $8.00^{\mathrm{e}}$ & $8.67^{\mathrm{f}, \mathrm{g}}$ & $15.67^{\mathrm{d}}$ \\
\hline Microsorum punctatum & $8.33^{\mathrm{g}}$ & $8.00^{\mathrm{e}}$ & $8.00^{\mathrm{e}}$ & $8.00^{\mathrm{g}}$ & $13.00^{\mathrm{f}}$ \\
\hline Nephrolepis cordifolia & $14.33^{\mathrm{c}}$ & $8.00^{\mathrm{e}}$ & $14.33^{\mathrm{d}}$ & $16.67^{\mathrm{b}}$ & $15.00^{\mathrm{e}}$ \\
\hline Oleandra pistillaris & $21.67^{\mathrm{a}}$ & $20.00^{\mathrm{a}}$ & $22.67^{\mathrm{a}}$ & $22.00^{\mathrm{a}}$ & $18.67^{\mathrm{c}}$ \\
\hline Pteridium aquilinum & $20.33^{\mathrm{b}}$ & $17.67^{\mathrm{b}}$ & $22.00^{\mathrm{a}}$ & $22.33^{\mathrm{a}}$ & $20.33^{\mathrm{a}}$ \\
\hline Pyrrosia piloselloides & $8.00^{\mathrm{g}}$ & $8.00^{\mathrm{e}}$ & $8.00^{\mathrm{e}}$ & $8.00^{\mathrm{g}}$ & $13.67^{\mathrm{f}}$ \\
\hline Selaginella usterii & $8.00^{\mathrm{g}}$ & $8.00^{\mathrm{e}}$ & $8.00^{\mathrm{e}}$ & $8.00^{\mathrm{g}}$ & $19.67^{\mathrm{a}, \mathrm{b}}$ \\
\hline
\end{tabular}

Legend: Superscript letters indicate means having similar letter have no significant difference at 0.5 level of significance

The antifungal equivalents of Diplazium esculentum, Peridium aquilinum, and Selaginella usterii were significantly high when compared to ketokonazole (Figure 4).

The differences in the antimicrobial effects of pteridophyte extracts are more likely due to the differences in their phytochemical components. The results obtained from the phytochemical analysis and the antimicrobial activity of these plants need further investigations that may lead to the development of antibiotics. In recent years, there has been a gradual revival of interest in the use of medicinal plants in developing countries because herbal medicines have been reported safe and without any adverse side effect especially when compared with synthetic drugs (Iniaghe et al. 2009). 

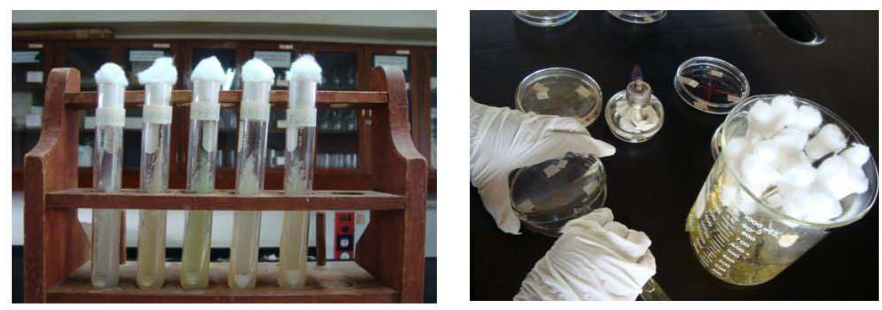

The five (5) microbial isolates used in the study

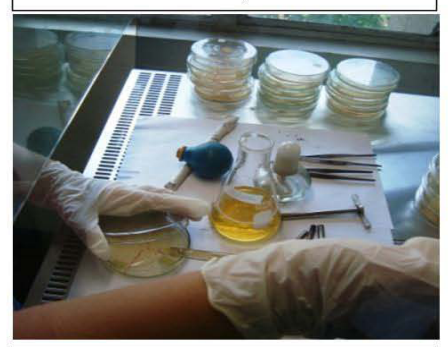

\section{Pouring of sterile MHA for the base agar}

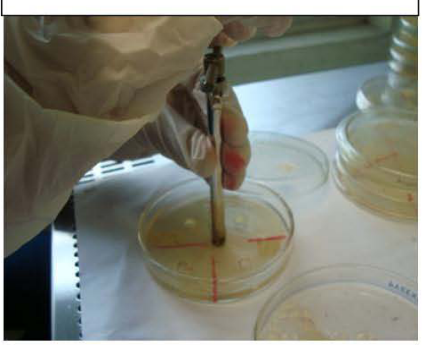

Inoculation of top agar with specific microorganism

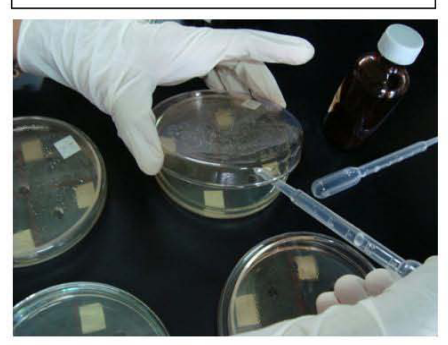

Delivery of plant extracts and antibiotics on the agar wells

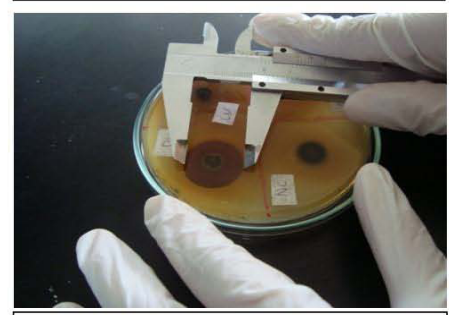

Measuring of the Zone of Inhibition $(\mathrm{mm})$ after 24 hours of Incubation
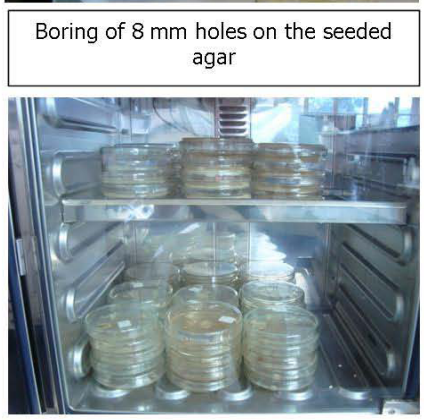

Incubation of cultures for 24 hours at $35-37^{\circ} \mathrm{C}$

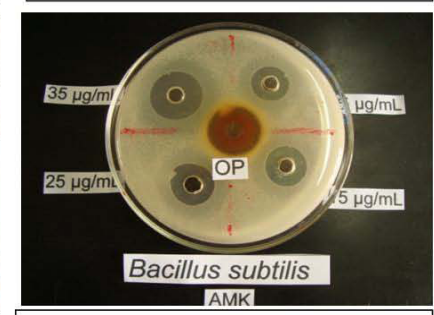

Zones of Inhibition showing microbial sensitivity

Plate 2. Protocols in Antimicrobial Screening 
Antimicrobial resistance continues to grow rapidly among key microbial pathogens such as Staphylococcus aureus, Pseudomonas spp, Streptococcus spp, and Enterobacteriaceae all around the world (Bax et al. 2003). Development of new antimicrobial agents is therefore imperative. The increased prevalence of antibiotic-resistant bacteria due to the extensive use of antibiotics may render the current antimicrobial agents insufficient to control some diseases caused by bacteria (Cowan 1999). Bax et al. (2003) have reported that global antibacterial resistance is becoming an increasing public health concern. Bacterial resistance to almost all available antibacterial agents has been reported. Ethnopharmacologists, botanists, microbiologists, and natural-product chemists are combing the earth for phytochemicals and "leads" which could be developed for the treatment of infectious diseases.

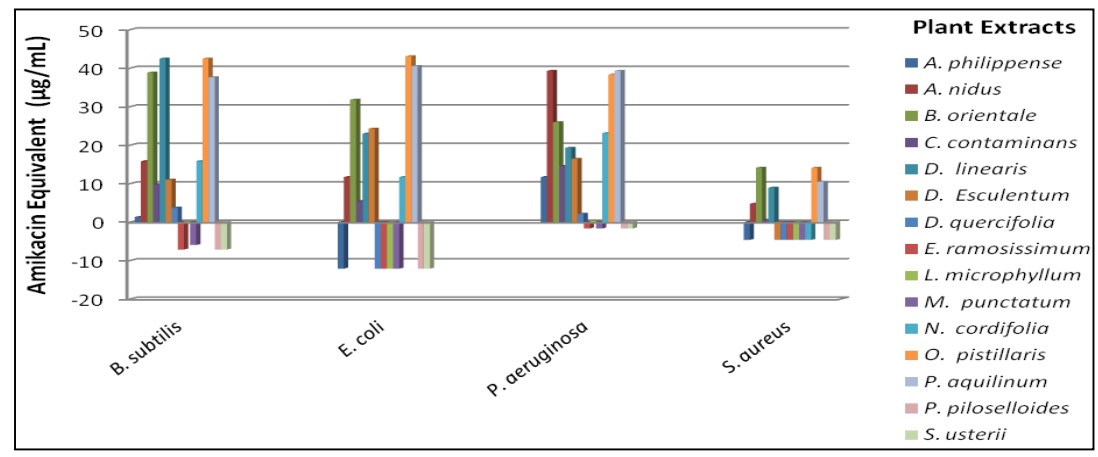

Figure 1. Antibiotic equivalents $(\mu \mathrm{g} / \mathrm{mL})$ of the ethanolic extracts when compared with Amikacin

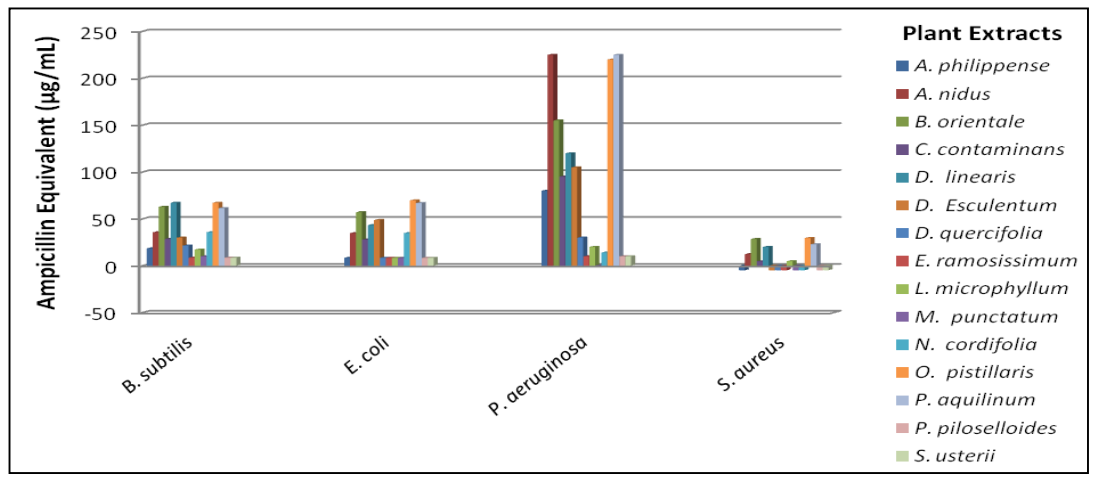

Figure 2. Antibiotic equivalents $(\mu \mathrm{g} / \mathrm{mL})$ of the ethanolic extracts when compared with Ampicillin 


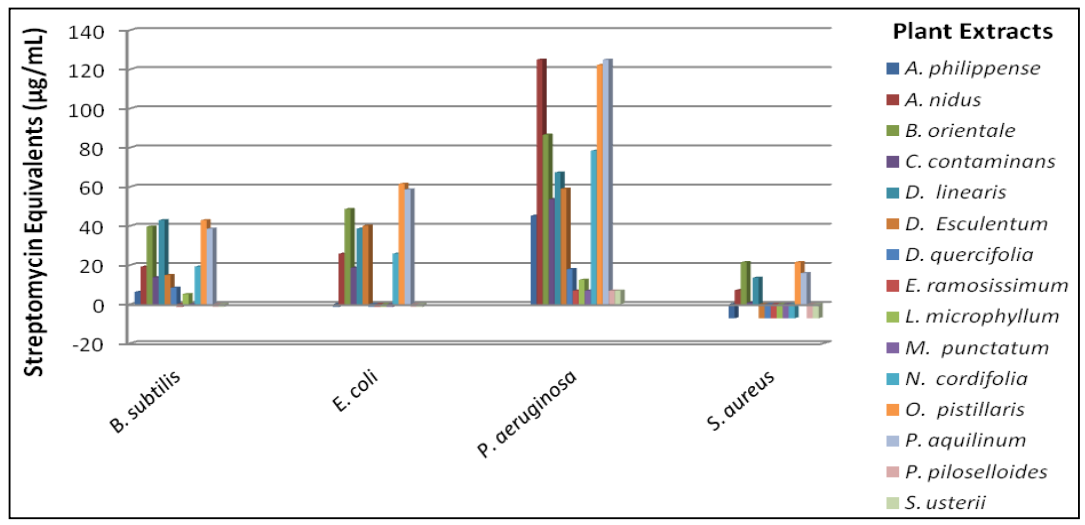

Figure 3. Antibiotic equivalents $(\mu \mathrm{g} / \mathrm{mL})$ of the ethanolic extracts when compared with Streptomycin

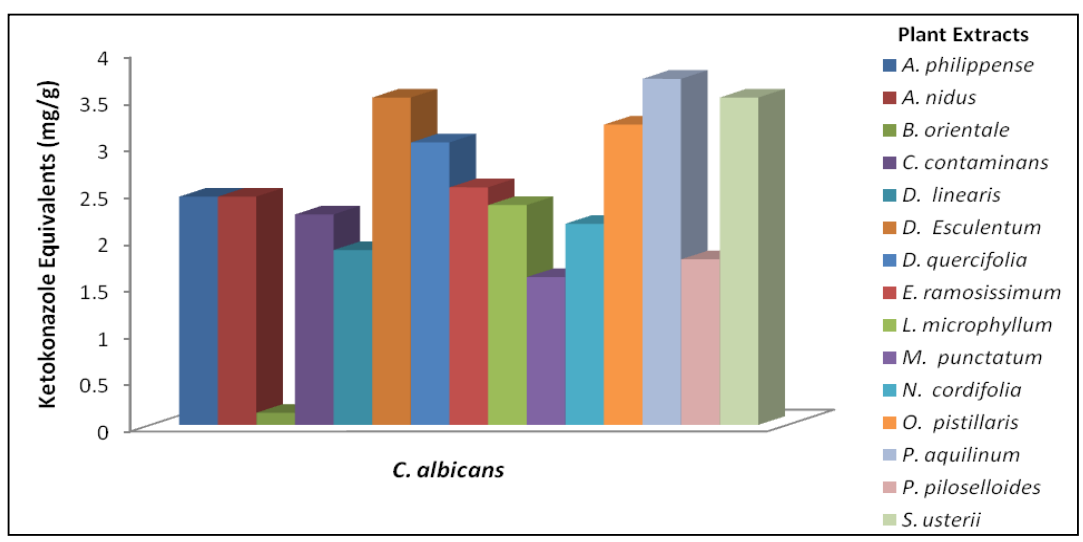

Figure 4. Antifungal equivalents $(\mathrm{mg} / \mathrm{g}$ ) of the ethanolic extracts when compared with Ketokonazole 


\section{Antipyretic Screening}

Pyrexia was induced in white rats with $1 \mathrm{~mL} / \mathrm{kg}$ BW of $15 \%$ baker's yeast administered intraperitoneally. The ethanolic pteridophyte extracts were evaluated for their antipyretic potential when compared with the control (NSS).

The fifteen (15) pteridophyte extracts screened for their antipyretic potential showed varying significant reduction in yeast-induced pyrexia in rats when compared with the control (NSS) (Table 3). Although there was a delay on the onset of lowering of rectal temperatures, the $800 \mathrm{mg} / \mathrm{kg} \mathrm{BW}$ pteridophyte extracts are still comparable in their antipyretic effect with the standard $150 \mathrm{mg} / \mathrm{kg}$ BW Paracetamol used in this study. In many studies, flavonoids have been reported to exhibit antipyretic effect (Mutalik et al. 2003). This confirms the results of the antipyretic activity of all the pteridophyte extracts in this study, which were all tested positive to flavonoids.

Table 3. Mean rectal temperature $\left({ }^{\circ} \mathrm{C}\right)$ readings of albino rats as affected by the plant extracts on taken every hour

\begin{tabular}{|c|c|c|c|c|c|c|}
\hline \multirow[b]{2}{*}{$\begin{array}{l}\text { Plant } \\
\text { Extract }\end{array}$} & \multicolumn{6}{|c|}{ Rectal Temperature $\left({ }^{\circ} \mathrm{C}\right)$} \\
\hline & & $\begin{array}{l}\text { Temperature } \\
\text { before Baker's } \\
\text { yeast injection }\end{array}$ & $\begin{array}{l}\text { The Initial } \\
\text { Temperature } \\
(19 \mathrm{hr})\end{array}$ & $20 \mathrm{hr}$ & $21 \mathrm{hr}$ & $22 \mathrm{hr}$ \\
\hline \multirow{2}{*}{$\begin{array}{l}\text { Adiantum } \\
\text { philippense }\end{array}$} & Mean & 36.88 & 37.90 & 38.46 & 38.16 & 37.8 \\
\hline & Calculated t (T-Test) & & & $3.62^{* *}$ & $4.97^{* *}$ & $2.57^{*}$ \\
\hline \multirow{2}{*}{$\begin{array}{l}\text { Asplenium } \\
\text { nidus }\end{array}$} & Mean & 36.88 & 37.88 & 37.76 & 37.92 & 38.32 \\
\hline & Calculated t (T-Test) & & & $6.46^{* *}$ & $6.27^{* *}$ & $4.41^{* *}$ \\
\hline \multirow{2}{*}{$\begin{array}{l}\text { Blechnum } \\
\text { orientale }\end{array}$} & Mean & 36.50 & 37.66 & 38.52 & 38.32 & 39.32 \\
\hline & Calculated t (T-Test) & & & $5.95^{* *}$ & $5.26^{* *}$ & $0.241^{\mathrm{ns}}$ \\
\hline \multirow{2}{*}{$\begin{array}{l}\text { Cyathea con- } \\
\text { taminans }\end{array}$} & Mean & 37.34 & 38.04 & 38.50 & 38.96 & 38.46 \\
\hline & Calculated t (T-Test) & & & $3.45^{* *}$ & $2.23^{\text {ns }}$ & $2.75^{*}$ \\
\hline \multirow{2}{*}{$\begin{array}{l}\text { Dicranopteris } \\
\text { linearis }\end{array}$} & Mean & 36.36 & 37.94 & 38.26 & 38.22 & 38.46 \\
\hline & Calculated t (T-Test) & & & $7.02^{* *}$ & $2.90^{*}$ & $3.85^{* *}$ \\
\hline \multirow{2}{*}{$\begin{array}{l}\text { Diplazium } \\
\text { esculentum }\end{array}$} & Mean & 36.88 & 38.08 & 37.84 & 37.94 & 37.70 \\
\hline & Calculated t (T-Test) & & & $6.60^{* *}$ & $5.70^{* *}$ & $5.82^{* *}$ \\
\hline \multirow{2}{*}{$\begin{array}{l}\text { Drynaria } \\
\text { quercifolia }\end{array}$} & Mean & 37.40 & 38.32 & 38.86 & 38.78 & 38.92 \\
\hline & Calculated $\mathrm{t}$ (T-Test) & & & $3.78^{* *}$ & $2.95^{*}$ & $3.85^{* *}$ \\
\hline \multirow{2}{*}{$\begin{array}{l}\text { Equisetum } \\
\text { ramosissimum }\end{array}$} & Mean & 36.42 & 38.24 & 38.36 & 37.78 & 38.14 \\
\hline & Calculated $\mathrm{t}$ (T-Test) & & & $7.94^{* *}$ & $4.84^{* *}$ & $2.79^{*}$ \\
\hline
\end{tabular}




\begin{tabular}{|c|c|c|c|c|c|c|}
\hline \multirow{2}{*}{$\begin{array}{l}\text { Lygodium } \\
\text { microphyllum }\end{array}$} & Mean & 36.44 & 37.88 & 38.24 & 38.14 & 38.70 \\
\hline & Calculated $\mathrm{t}$ (T-Test) & & & $9.90^{* *}$ & $6.14^{* *}$ & $3.16^{*}$ \\
\hline \multirow{2}{*}{$\begin{array}{l}\text { Microsorum } \\
\text { punctatum }\end{array}$} & Mean & 36.74 & 37.84 & 38.48 & 38.36 & 38.38 \\
\hline & Calculated $\mathrm{t}$ (T-Test) & & & $3.97^{* *}$ & $4.21^{* *}$ & $2.80^{*}$ \\
\hline \multirow{2}{*}{$\begin{array}{l}\text { Nephrolepis } \\
\text { cordifolia }\end{array}$} & Mean & 36.28 & 37.82 & 37.92 & 38.42 & 38.40 \\
\hline & Calculated t (T-Test) & & & $6.96^{* *}$ & $5.78^{* *}$ & $4.09^{* *}$ \\
\hline \multirow{2}{*}{$\begin{array}{l}\text { Oleandra } \\
\text { pistillaris }\end{array}$} & Mean & 36.38 & 38.16 & 38.22 & 38.12 & 39.22 \\
\hline & Calculated $\mathrm{t}$ (T-Test) & & & $5.78^{* *}$ & $5.54^{* *}$ & $0.601^{\mathrm{ns}}$ \\
\hline \multirow{2}{*}{$\begin{array}{l}\text { Pteridium } \\
\text { aquilinum }\end{array}$} & Mean & 37.26 & 38.32 & 38.78 & 38.84 & 38.72 \\
\hline & Calculated t (T-Test) & & & $3.21^{*}$ & $2.97^{*}$ & $2.55^{*}$ \\
\hline \multirow{2}{*}{$\begin{array}{l}\text { Pyrrosia pilo- } \\
\text { selloides }\end{array}$} & Mean & 37.48 & 38.24 & 38.72 & 39.22 & 38.88 \\
\hline & Calculated t (T-Test) & & & $5.37^{* *}$ & $1.74^{\mathrm{ns}}$ & $2.01^{\mathrm{ns}}$ \\
\hline \multirow{2}{*}{$\begin{array}{l}\text { Selaginella } \\
\text { usterii }\end{array}$} & Mean & 36.50 & 37.46 & 38.84 & 38.88 & 39.42 \\
\hline & Calculated t (T-Test) & & & $4.26^{* *}$ & $1.93^{\mathrm{ns}}$ & $0.145^{\text {ns }}$ \\
\hline \multirow{2}{*}{$\begin{array}{l}\text { Paracetamol } \\
150 \mathrm{mg} / \mathrm{kg} \\
\text { BW }\end{array}$} & Mean & 37.40 & 38.70 & 38.02 & 37.9 & 37.44 \\
\hline & Calculated t (T-Test) & & & $11.00^{* *}$ & $5.40^{* *}$ & $4.82^{* *}$ \\
\hline NSS & Mean & 37.64 & 38.94 & 39.46 & 39.66 & 39.38 \\
\hline
\end{tabular}

$\mathrm{t}_{.05}=2.31 \mathrm{t}_{.01}=3.36$

\section{Anti-Inflammatory Screening}

The 15 species of pteridophyte extracts were screened for their antiinflammatory activity. As observed, all extracts significantly reduced inflammation among the male albino rats within six (6) hours of extract administration except for the $400 \mathrm{mg} / \mathrm{kg} \mathrm{BW}$ of Pyrossia piloselloides. The two doses, $400 \mathrm{mg} / \mathrm{kg} \mathrm{BW}$ and $800 \mathrm{mg} / \mathrm{kg} \mathrm{BW}$ of the extracts produced a dose-dependent effect on the inflamed paw of rats (Table 4). 
Table 4. Paw thickness reading $(\mathrm{mm})$ of albino rats over a period of 6 hours in anti-inflammatory screening of pteridophyte ethanol extracts using egg albumin-induced rat paw edema

\begin{tabular}{|c|c|c|c|c|c|c|c|c|}
\hline \multirow[b]{2}{*}{$\begin{array}{l}\text { Plant } \\
\text { Extracts }\end{array}$} & \multirow[b]{2}{*}{ Treatments } & \multirow[b]{2}{*}{$\begin{array}{l}\text { Thickness } \\
\text { of Paw } \\
\text { (mm) } \\
\text { before egg- } \\
\text { albumin } \\
\text { injection }\end{array}$} & \multicolumn{6}{|c|}{ Paw thickness reading over a period of 6 hours in $\mathrm{mm}$} \\
\hline & & & $2 \mathrm{hrs}$ & $\begin{array}{c}\text { \% paw } \\
\text { reduc- } \\
\text { tion }\end{array}$ & 4 hrs & $\begin{array}{l}\% \text { paw } \\
\text { reduc- } \\
\text { tion }\end{array}$ & 6 hrs & $\begin{array}{l}\text { \% paw } \\
\text { reduc- } \\
\text { tion }\end{array}$ \\
\hline \multirow{2}{*}{ A. philippense } & $400 \mathrm{mg} / \mathrm{Kg} \mathrm{BW}$ & 2.78 & $6.52^{*}$ & 23.05 & $5.44^{*}$ & 30.37 & $4.06^{* *}$ & 54.93 \\
\hline & $800 \mathrm{mg} / \mathrm{Kg} \mathrm{BW}$ & 2.46 & $5.86^{* *}$ & 30.04 & $5.24^{* *}$ & 27.23 & $4.00^{* *}$ & 45.77 \\
\hline \multirow{2}{*}{ A. nidus } & $400 \mathrm{mg} / \mathrm{Kg} \mathrm{BW}$ & 2.34 & $6.04^{*}$ & 23.87 & $4.88^{* *}$ & 33.51 & $3.16^{* *}$ & 71.13 \\
\hline & $800 \mathrm{mg} / \mathrm{Kg}$ BW & 2.64 & $6.00^{* *}$ & 30.86 & $4.68^{* *}$ & 46.60 & $3.12^{* *}$ & 83.10 \\
\hline \multirow{2}{*}{ B. orientale } & $400 \mathrm{mg} / \mathrm{Kg}$ BW & 2.64 & $6.22^{*}$ & 26.33 & $5.48^{\mathrm{ns}}$ & 25.65 & $4.20^{*}$ & 45.07 \\
\hline & $800 \mathrm{mg} / \mathrm{Kg} \mathrm{BW}$ & 2.76 & $5.90^{* *}$ & 35.39 & $4.18^{* *}$ & 62.83 & $3.74^{* *}$ & 65.49 \\
\hline \multirow{2}{*}{ C. contaminans } & $400 \mathrm{mg} / \mathrm{Kg}$ BW & 2.58 & $6.88^{*}$ & 11.52 & $5.40^{* *}$ & 26.18 & $4.22^{* *}$ & 42.25 \\
\hline & $800 \mathrm{mg} / \mathrm{Kg} \mathrm{BW}$ & 2.56 & $6.34^{* *}$ & 22.22 & $5.38^{* *}$ & 26.18 & $3.96^{* *}$ & 50.70 \\
\hline \multirow{2}{*}{ D. linearis } & $400 \mathrm{mg} / \mathrm{Kg}$ BW & 2.54 & $6.90^{\mathrm{ns}}$ & 10.29 & $5.66^{\mathrm{ns}}$ & 18.32 & $4.38^{*}$ & 35.21 \\
\hline & $800 \mathrm{mg} / \mathrm{Kg}$ BW & 2.48 & $5.82^{* *}$ & 31.28 & $4.78^{* *}$ & 39.79 & $3.98^{*}$ & 47.18 \\
\hline \multirow{2}{*}{ D. esculentum } & $400 \mathrm{mg} / \mathrm{Kg}$ BW & 2.66 & $6.46^{\mathrm{ns}}$ & 21.81 & $5.50^{*}$ & 25.65 & $4.18^{* *}$ & 46.48 \\
\hline & $800 \mathrm{mg} / \mathrm{Kg}$ BW & 2.26 & $6.40^{* *}$ & 14.81 & $4.80^{* *}$ & 33.51 & $3.62^{* *}$ & 52.11 \\
\hline \multirow{2}{*}{ D. quercifolia } & $400 \mathrm{mg} / \mathrm{Kg}$ BW & 2.52 & $6.66^{* *}$ & 14.81 & $5.26^{* *}$ & 28.27 & $4.14^{* *}$ & 42.96 \\
\hline & $800 \mathrm{mg} / \mathrm{Kg}$ BW & 2.32 & $5.96^{* *}$ & 25.10 & $4.94^{* *}$ & 31.42 & $3.60^{* *}$ & 54.93 \\
\hline \multirow{2}{*}{ E. ramosissimum } & $400 \mathrm{mg} / \mathrm{Kg} \mathrm{BW}$ & 2.50 & $6.62^{*}$ & 15.23 & $5.80^{\mathrm{ns}}$ & 13.61 & $4.32^{* *}$ & 35.92 \\
\hline & $800 \mathrm{mg} / \mathrm{Kg}$ BW & 2.54 & $6.16^{* *}$ & 25.51 & $4.92^{*}$ & 37.70 & $3.96^{* *}$ & 50.00 \\
\hline \multirow{2}{*}{ L. microphyllum } & $400 \mathrm{mg} / \mathrm{Kg}$ BW & 2.32 & $6.68^{*}$ & 9.92 & $5.46^{*}$ & 17.80 & $4.20^{* *}$ & 33.80 \\
\hline & $800 \mathrm{mg} / \mathrm{Kg}$ BW & 2.28 & $6.54^{*}$ & 12.35 & $5.22^{* *}$ & 23.04 & $4.14^{* *}$ & 34.51 \\
\hline \multirow{2}{*}{ M. punctatum } & $400 \mathrm{mg} / \mathrm{Kg}$ BW & 2.46 & $6.54^{*}$ & 16.05 & $5.90^{\mathrm{ns}}$ & 26.18 & $4.68^{*}$ & 21.83 \\
\hline & $800 \mathrm{mg} / \mathrm{Kg}$ BW & 2.46 & $6.06^{* *}$ & 25.93 & $5.24^{* *}$ & 27.23 & $4.12^{* *}$ & 41.55 \\
\hline \multirow{2}{*}{ N. cordifolia } & $400 \mathrm{mg} / \mathrm{Kg} \mathrm{BW}$ & 2.74 & $7.10^{\mathrm{ns}}$ & 10.29 & $5.94^{\mathrm{n}} \mathrm{s}$ & 16.23 & $4.60^{*}$ & 34.51 \\
\hline & $800 \mathrm{mg} / \mathrm{Kg}$ BW & 2.42 & $6.68^{\mathrm{ns}}$ & 12.35 & $4.94^{* *}$ & 34.03 & $4.18^{* *}$ & 38.03 \\
\hline \multirow{2}{*}{ O. pistillaris } & $400 \mathrm{mg} / \mathrm{Kg}$ BW & 2.44 & $7.52^{\mathrm{ns}}$ & -4.53 & $6.26^{\mathrm{ns}}$ & 0.00 & $4.48^{* *}$ & 28.17 \\
\hline & $800 \mathrm{mg} / \mathrm{Kg}$ BW & 2.46 & $7.20^{\mathrm{ns}}$ & 2.47 & $5.52^{*}$ & 19.90 & $4.14^{* *}$ & 40.85 \\
\hline \multirow{2}{*}{ P. aquilinum } & $400 \mathrm{mg} / \mathrm{Kg}$ BW & 2.42 & $7.06^{\mathrm{ns}}$ & 4.53 & $5.82^{\mathrm{ns}}$ & 10.99 & $4.64^{*}$ & 24.65 \\
\hline & $800 \mathrm{mg} / \mathrm{Kg} \mathrm{BW}$ & 2.22 & $6.66^{*}$ & 37.04 & $5.34^{* *}$ & 18.32 & $4.28^{*}$ & 27.46 \\
\hline \multirow{2}{*}{ P. piloselloides } & $400 \mathrm{mg} / \mathrm{Kg}$ BW & 2.62 & $7.30^{\mathrm{ns}}$ & 3.7 & $6.30^{\mathrm{ns}}$ & 3.66 & $4.84^{\mathrm{ns}}$ & 21.83 \\
\hline & $800 \mathrm{mg} / \mathrm{Kg} \mathrm{BW}$ & 2.52 & $6.60^{*}$ & 16.05 & $5.70^{*}$ & 16.75 & $4.34^{* *}$ & 35.91 \\
\hline \multirow{2}{*}{ S. usterii } & $400 \mathrm{mg} / \mathrm{Kg} \mathrm{BW}$ & 2.54 & $6.44^{*}$ & 19.75 & $5.52^{*}$ & 22.00 & $4.54^{*}$ & 29.58 \\
\hline & $800 \mathrm{mg} / \mathrm{Kg} \mathrm{BW}$ & 2.52 & $6.14^{* *}$ & 25.51 & $5.34^{* *}$ & 26.18 & $3.94^{* *}$ & 50.00 \\
\hline \multirow[t]{2}{*}{ Control } & $\begin{array}{l}50 \mathrm{mg} / \mathrm{Kg} \\
\text { Diclofenac }\end{array}$ & 2.64 & $5.56^{* *}$ & 39.92 & $4.10^{* *}$ & 61.78 & $2.82^{* *}$ & 93.66 \\
\hline & NSS & 2.50 & 7.36 & & 6.32 & & 5.34 & \\
\hline
\end{tabular}

${ }^{*}$ significant at $\mathrm{P}<0.05,{ }^{* *}$ significant at $\mathrm{P}<0.01$, ${ }^{\text {ns }}$ - not significant 
There were slight delays on the effect of some pteridophyte extracts in inhibiting paw edema. This may be due to the slow absorption of the herbal preparations or metabolites in the rats as a response of living tissues to injury. Inflammation involves a complex array of enzyme activation, mediator release, extravasations of fluid, cell migration, tissue breakdown and repair (Elias and Rao 1988). The early phase of inflammation is mainly mediated by histamine and serotonin. Histamine and other mediators of inflammation increases vascular permeability at various times after injury (Whaley and Burt 1996).

Several investigations have repeatedly proven that different flavonoid molecules exhibit anti-inflammatory functions. Thus, the anti-inflammatory activities of flavonols (quercetin, rutin and morin) and flavanones (hesperetin and hesperidin) were investigated in acute and chronic inflammation in animal models. The most important compound in reducing paw edema induced by carrageenan is quercetin (Havsteen 2002). On the other hand Paradkar et al. (2004) demonstrated that an isoflavone-containing diet with daidzin, glycitin, genistein and their glucosides, can modulate the inflammatory reaction in the intestine and liver of mice after lipopolysaccharide injection. Thus, flavaonoids in the form of flavonols, flavanones or isofalvon can exhibit anti-inflammatory activities.

\section{CONCLUSIONS}

Based on the findings of the present study, the following conclusions are drawn:

1. The phytochemical components namely alkaloids, saponins, flavonoids, and tannins were present in frond ethanolic extract of the selected pteridophytes. Anthraquinones were not detected in the ethanolic extract of all pteridophytes evaluated.

2. The ethanolic frond extracts of the pteridophytes exhibited antifungal activity on Candida albicans except in Blechnum orientale extract.

3. Some of the ethanolic frond extract of the pteridophytes exhibited antibacterial activity on Gram positive Bacillus subtilis and Staphylococcus aureus and on Gram negative Escherichia coli and Pseudomonas aeruginosa. Among the fifteen (15) pteridophyte ethanolic extracts, Oleandra pistillaris and Pteridium aquilinum manifested the greatest antibacterial and antifungal activities. 
4. The ethanolic frond extract of all the pteridophytes exhibited antipyretic and anti-inflammatory properties.

\section{RECOMMENDATIONS}

The present experimental findings suggest that the fifteen (15) pteridophytes have varying antimycotic, antibacterial, antipyretic, and anti-inflammatory potentials. To further maximize the medicinal uses of these plants, we recommend the following to further evaluate these pteridophyte potentials:

1. to perform quantitative phytochemical identification and isolation on their ethanolic extracts

2. to further investigate the biochemical pathways using purified chemical constituents of the pteridophyte extracts which may result in the development of potent antipyretic and anti-inflammatory agent with low toxicity and better therapeutic index

3. to design and perform pharmacodynamic studies to establish the specific mechanism of antipyretic and anti-inflammatory action of the different plant extracts

\section{LITERATURE CITED}

Al-Ghamdi, M.S.

2001 Anti-inflammatory, analgesic and antipyretic activity of Nigella sativa. J. Ethnopharmacol. 76: $45-48$.

Amoroso, V. B.

2013 Philippine medicinal ferns and Lycopods. Central Mindanao University, Musuan, Bukidnon.

Bax, R., N. Mullan, and F. Verhoef

2000 The millennium bugs - the need for and development of new antibacterial. International Journal of Antimicrobial Agents. 16: 51-59.

Cos, P., A.J. Vlietinck, D.V. Berghe, and L. Maes

2006 Anti-infective potential of natural products: How to develop a stronger in vitro 'proof-of-concept. J. Ethnopharmacol. 106: 290-302. 
Cowan, M.M.

1999 Plant products as antimicrobial agents.Clinical Microbiology Reviews 12: $564-582$.

Elias, G. and M.N. Rao

1988 Inhibition of albumin denaturation and anti-inflammatory activity of dehydrozingerone and its analogs. Indian. J. Exp. Biol. 26: 540-542.

Funatogawa, K., S. Hayashi, H. Shimomura, Yoshida, T. Hatano, H. Ito, and Y. Hirai.

2004 Antibacterial activity of hydrolyzable tannins derived from medicinal plants against Helicobacter pylori. Microbiol. Immunol. 48 (4): 251-61.

Guevarra, B. Q. (ed.).

2005 A Guidebook to Plant Screening: Phytochemical and Biological. UST Publishing House, Philippines.

Havsteen, B.H.

2002 The biochemistry and medical significance of the flavonoids.Pharmacol. Ther. 96 (2-3): 67-202.

Khan, A.,A. Baki, A. Alim Al-Bari, S. Hasan, A. Mosaddik, M. Rahman, and E. Haque

2007 Antipyretic activity of roots of Laportea crenulata Gaud in rabbit. Research Journal of Medicine and Medical Sciences, 2(2):58-61.

Kolodziej, H. and A.F. Kiderlen

2005 Antileishmanial activity and immune modulatory effects of tannins and related compounds on Leishmani a parasitised RAW 264.7 cells. Phytochemistry. 66 (17): 2056-71.

Khan, M., M. Kibm, and B. Oinoloso

2003 Antimicrobial activity of the alkaloidal constituents of the root bark of Eupomatia lourina. Phannaceut. Biol.41: 277-280.

Iniaghe, O.M., S.O. Malomo, AND J.O. Adebayo

2009 Proximate composition and phytochemical constituents of leaves of 
some acalypha species. Pak. J. Nutrit. 8: 256-258.

Mojab, F., M. Kamalinejad, N. Ghaderi, and H.R. Vahidipour

2003 Phytochemical Screening of Some Species of Iranian Plants. Iranian Journal of Pharmaceutical Research.77-82.

Mori, H., N. Yoshimi, H. Iwata, Y. Mori, A. Hara, T. Tanaka, and K. Kawai.

1990 Carcinogenicity of naturally occurring 1-hydroxyanthraquinone in rats: Induction of large bowel, liver and stomach neoplasms. Carcinogenesis. 11:799-802.

Mutalik S., Paridhavi K., Mallikarjuna Rao C., Udupa N

2003 Antipyretic and analgesic effect of leaves of Solanum melongena Linn in rodents. Indian J. Pharmacol. 35: 312-315.

Paradkar, P.N., P.S. Blum, M.A. Berhow, K. Bauman, S.m., Kuo

2004 Dietary isoflavones suppress endotoxin-induced inflammatory reaction in liver and intestine. Cancer Lett. 215:21-8.

Perez, G. R. M.

1996 Anti-inflammatory activity of Ambrosia artemisiaefolia and Rheo spathacea. Phytomed. 3(2): 163-167.

Porter, L.J.

1989 Tannins in Methods in plant Biochemistry (plant phenolics), eds. Dey, P.M. and Harborne, J.B., Academic Press, London 1: 389-419.

Price, K.R., I.T. Johnson, and G.R. Fenwick

1997 The chemistry and biological significance of saponins in foods and feedingstuffs. Crit Rev Food Sci Nutr. 26 (1):27-135.

Raghavendra, M.P., S. Satish, and K.A. Raveesha

2008 In vitro antibacterial potential of alkaloids of Samanea saman (Jacq.) Merr. Against Xanthomonas and human pathogenic bacteria. World J. Agric. Sci. 4: 100-105. 
Rao, A.V. And R. Koratkar

1997 Anticarcinogenic effects of saponins and phytosterols. Antinutrients and Phytochemicals in Food. 18: 313-324.

Salawu, O.A., B.A. Chindo, A.Y. Tijani, and B. Adzu

2008 Analgesic, anti-inflammatory, antipyretic and antiplasmodial effects of the methanolic extract of Crossopteryx febrifuga. Journal of Medicinal Plants Research.Vol. 2(8):213-218.

Sonnenberg, A. and A.D. Müller

1993 Constipation and cathartics as risk factors of colorectal cancer: A metaanalysis. Pharmacology, 47 (Suppl. 1) 224-233.

Vimala, R., S. Nagarajan, M. Alam, T. Susan and S. Joy

1997 Anti-inflammatory and antipyretic activity of Michelia champaca Linn. (White variety), Ixora brachiata Roxb. and Rhynchosia cana (Wild.) D. C. flower extract. Indian Journal of experimental Biology. 35: 13101314.

Whaley, K. and A.D. Burt

1996 Inflammation, healing and repair, in: MacSween RMN, Whaley K, Muir's Textbook of Pathology 13th edn: Arnold: London. pp112-165.

Winter, C.A., E.A. Risley and G.W. Nuss

1962 Carrageenan-induced oedema in the hind paw of rat as an assay for antiinflammatory activity. ProcSoc. Exp. Biol. Ther. 111: 544-547.

Zabri, H., C. Kodjo, A. Benie and Y.A. Bekro

2008 Phytochemical screening and determination of flavonoids in Secamone afzelii (Asclepiadaceae) extracts. African Journal of Pure and Applied Chemistry.2 (8): 080-082.
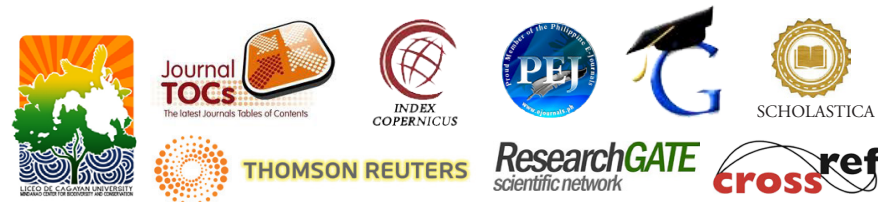

THOMSON REUTERS

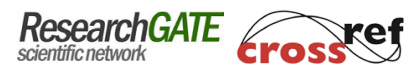

